\title{
A framework for identifying the competencies of senior production managers of Holding Companies (The case of Golrang industrial group)
}

\author{
${ }^{1}$ Gholamreza Jandaghi, ${ }^{2}$ Jabbar Babashahi, ${ }^{3}$ Roya Kavoosi \\ ${ }^{1}$ Professor, Faculty of Management and Accounting, Farabi College, University of Tehran, Iran \\ ${ }^{2}$ Assistant Professor, Faculty of Management and Accounting, Farabi College, University of \\ Tehran, Iran \\ ${ }^{3}$ MA, Faculty of Management and Accounting, Farabi College, University of Tehran, Iran \\ 1'jandaghi@ut.ac.ir, 2j.babashahi@ut.ac.ir, ${ }^{3}$ roya.kavoosi@ut.ac.ir
}

Keywords: identifying; competencies; Holding Companies; Golrang industrial group

\begin{abstract}
Today the need of identify ways for increasing competitive advantage is more tangible because the business world have been increasingly changed. A successful organization is an organization where human resources have the required competencies to achieve business success and the strategic objectives of the organization. so the competency-based human resource management becomes important.The first step in this area is to identify key competencies of managers .Many studies have been done in this area to provide a human resource competency model for organization. National prospect of Iran is having important goals, such as becoming the first power of economic, science and technology in the region and to engage constructively and effectively in international relations, for achieving these goals we requires competent managers in the public and private sector organizations.

Competency models, which should be designed for all key positions in the company, show what competencies are necessary for individual position(s). The question is what the key competencies for each position are. Main objective of this paper is to offers a framework to identify and prioritize Senior Product Managers competencies at Golrang Industrial Group.
\end{abstract}

\section{INTRODUCTION}

In view of the knowledge-based nature of competition, global managers need a broad range of managerial competencies. Especially, successful global management will think strategically in a worldwide context, but act like a local organization in each national market (Sheridan, 1997). According to McKenna (1998), identifying management competencies would enable managers to perform more effectively, and lead to develop the dimensions of effective management and leadership behavior. Moreover, Rosen and Digh (2001) indicate that global manager competencies are the new leadership competencies required for business success in today's multicultural and global economy.

\section{LITERATURE REVIEW}

\section{Holding Company}

Bonbright and Means (1969) defines a holding company as "any company, incorporated or unincorporated, which is in a position to control, or materially to influence, the management of one or more other companies by virtue, in part at least, of its common control and operated as part of a system. The BusinessDictionary.com (n.d.) refers to a holding company as "a type of business organization that allows a firm (called parent) and its directors to control or influence other firms (called subsidiaries). The legal definition of a holding company varies with the legal system. Some require holding of a majority ( 80 percent) or the entire (100 percent) voting shares of the subsidiary whereas other require as little as five percent." In all these three definitions, the important role of a holding company that is emphasized is the "control" of other companies through ownership of stocks which gives it the "power" to elect management. 
Hanafizadeh and Moayer (2008) classifies holding companies into: 1) investment holding company, and 2) managerial holding company. The investment holding company derives its profits solely from the investments in the securities of its subsidiaries. The managerial holding company in addition to earning from subsidiary's profits, also intervenes in the subsidiaries' transactions. A third type of holding company is the operating holding company that is also in the business of selling some products or services to its own customers in addition to having investments in subsidiary firms. The holding company emerged as a common form of business organization in the United States around 1900. Prior to 1888, US holding companies were founded by ownership of securities in the other company or companies." Ballantine (1946) refers to a parent or holding company as one which controls another as a subsidiary or affiliate by the power to elect its management. Affiliates are those concerns which are subject to special legislative acts given as charter privileges for railroad and communication firms. It was only in 1888 when the state of New Jersey added to its general corporation law provisions allowing a corporation to hold stocks in other corporations (Bonbright \& Means, 1969, p. 57). In Pennsylvania, between 1868 and 1872, about forty corporations were established as pure holding companies by special acts of the Pennsylvania legislative (Bonbright \& Means, 1969, p. 59).

Golrang Industrial Group (GIG) is one of the most important producing companies in IRAN that include various SBUs. It is one of the most dynamic economic groups and reflects the efforts of private sectors. 8500 employees have been employed in this group and its vision is to have 100000 employees until 2025. GIG includes of about 100 companies; the most important ones are: Pakshoo Production \& Chemical Co., Marinasun, GolPakhsh-e-Aval, Golrang Pakhsh, Arian Pakhsh Pishro, Golbarg Baharan, Padideh Shimi Paydar, GIG Pharmaceutical Investment Co., Padideh Shimi Nili, and etc.

This group's main purpose is being among the 500 largest corporations in the world relying on wellknown brands. GIG offers high-quality products and services. All people will recognize GIG via reputed brands, leading in the market, commitment to ethics and sustainable growth. GIG Strategic Goals are Increasing the export share to $20 \%$, Increasing the number of product categories to 132 numbers, Increasing the number of SBUs to 20 units, Development of, at least, 70 brands with selling upper than $100 \mathrm{M} \$$, Increasing the number of branches to 344 numbers, Keeping the "Average Annual Growth" of "Profit Margin" at, at least, 1\%, Increasing the market share to $60 \%$ through differentiation strategy and based on Best Cost-Benefit, Increasing the sales per capita to 25 Billion Rial and Increasing the number of staff to 100000 members till 2025. So to achieve these goals GIG must have competent managers. Because of the specific and special coordinates of Golrang Industrial Group, having competent senior product manager is essential to maintain competitive advantage. The objective of this article is to identify Senior Product Managers competency at GIG.

\section{COMPETENCY-BASED APPROACH}

"Competency" is a commonly used term for people's asserting of their working potential in real activities. At present, there are many definitions of this term. In principle, there are two main meanings on which individual definitions of competencies are generally based. The first characterises competencies as a power and a scope of authority associated with a certain person or body. The second meaning of competencies refers to the capacity, i.e. abilities to perform a certain activity, to have certain general and specific characteristics and skills, to be qualified in the given area. Generally it can be said that it is a set of specific knowledge, abilities, skills, traits, motives, attitudes and values essential for the personal development and successfulparticipation of each person in an organization. That in fact means behaviour necessary for achieving the required level of performance. This refers to the performance aspect of a competency determined by the level of inputs (knowledge, abilities, skills, traits, motives, attitudes and values) and measured by the analysis of outputs (real behaviour and results) (Martina, et, al., 2012). 
According to its development, it is possible to divide competencies into three main development phases. The first phase consists of individual competencies (White, 1959; McClelland, 1973; Boyatzis, 1982; Schroder, 1989; Woodruffe, 1992; Spencer \& Spencer, 1993; Carroll \& McCrackin, 1997). The second phase is based on the possibility of managing competencies in an organization by means of competency models (Mansfield, 1996; McLagan, 1997; Lucia \& Lepsinger, 1999; Rothwell \& Lindholm, 1999). The third phase is the identification of core competencies, a sum of organization key organizational competencies that may be exploited to gain competitive advantage (Prahalad \& Hamel, 1990; Ulrich \& Lake, 1991; Gallon, Stillman, \& Coates, 1995; Coyne, Hall, \& Clifford, 1997; Rothwell \& Lindholm, 1999; Delamare \& Wintertone, 2005). The survey concentrated on the managerial competencies. Managerial competencies are a specific type of individual competencies. Based on a survey, Boyatzis (1982) defined competencies as a human ability to behave in a way to meet job requirements in parameters given by the organization's environment and thus to achieve the required results. In his work he defined threshold competencies as competencies crucial for managerial work, however, not having any significant causal relationship to its efficiency and better results. Managerial competencies are 132 Journal of Competitiveness activities, knowledge, skills or attitudes and perhaps also personal characteristics necessary to improve management performance. Schroder (1989) uses a similar classification of competencies and distinguishes between basic competencies and high performance competencies. Basic competencies are defined as knowledge and skills essential for the performance of a manager's job. They relate to specific tasks and guarantee manager's personal efficiency. High performance competencies are relatively stable manifestations of behavior thanks to which the entire teams led by the manager accomplish excellent above standard results. High performance competencies are further subdivided into cognitive, motivational, directional and performance competencies. According to Spencer and Spencer (1993), managerial competencies are a specialized subset of the competencies, expressing the intention to have certain specific effects. These specific intentions are particularly important for managers. Hogg (1993) adds that managerial competencies lead to the demonstration of skills and abilities, which result in effective performance within an occupational area. According to Boyatzis (2008), research published over the last 30 years or so shows that outstanding managers appear to require the threshold clusters of competencies (expertise and experience, knowledge, an assortment of basic cognitive competencies) and the clusters of competencies differentiating outstanding from average performers (cognitive competencies, emotional intelligence competencies, social intelligence competencies). Additionally, the literature also identifies other components of managerial competencies which also contribute significantly to career success (Tate, 1995; Carroll \& McCrackin, 1997; Woodall \& Winstanley, 1998; Lucia \& Lepsinger, 1999; Winterton \& Winterton, 1999; Birdir \& Pearson, 2000; Sanghi, 2007; Horng, Hsu, Liu, Lin \& Tsai, 2011). Managerial competencies that are required for normal and superior performance determine managerial competency models. These performance-based competencies are assessed through observed behaviours (Chong 2011).

\section{KATZ COMPETENCY FRAMEWORK}

Katz (1974) has provided a legacy conceptual framework. Katz's (1974) three skill approach stated that the use of each of the skills varies with the level of management responsibility. At lower levels technical skill is indispensable to efficient operation. As the manager moves further from actual operations the need for technical skill decreases. On the other hand, at the top level conceptual skill becomes increasingly critical for successful administration. Human relation skills are the area that is essential at all levels of management according to Katz (1974).

Table 1 Katz Conceptual Framework

\begin{tabular}{|c|c|}
\hline Technical Skill & Understanding of specific kind of activity, involves specialized Knowledge. \\
\hline Human Skill & Primarily concerned with working with peaple. \\
\hline Conceptual Skill & Ability to see the enterprise as a whole. \\
\hline
\end{tabular}


Technical skill implies an understanding of, and proficiency in a specific kind of activity, particularly one involving methods, processes, procedures, or techniques. Technical skill involves specialized knowledge, analytical ability within that specialty, and facility in the use of the tools and techniques of the specific discipline (Katz, 1974).

Human skill implies the ability to work effectively as a group member and to build cooperative effort within the team being lead. Human skill is primarily concerned with working with people (Katz, 1974).

Conceptual skill involves the ability to see the enterprise as a whole; it includes recognizing how the various functions of the organization depend upon one another, and how changes in any one part affect all the others; and it extends to visualizing the relationship of the individual business to the industry, the community, and the political, social, and economic forces of the nation as a whole (Katz, 1974).

The competency model chosen for this research is the Katz (1974) model. He noted that these skills are related yet have separate characteristics. Katz also noted that the three skills range in level of complexity and in which circumstances they can be applied. The other aspect of the Katz approach is that technical, human and conceptual skills can be learned which is different from Trait Theory and others that contend leadership ability is inherent and leaders are "born" with these personality traits. The strength of this leadership framework is that it is a much more useful way to look at leadership and is applicable to any setting.

Following the above discussions, GIG Senior Product Managers Conceptual Model is presented in Table 1.

\section{METHODOLOGY}

The study developed a pre-structured questionnaire to gather primary data. The questionnaire consisted of 28 questions, Questions mainly required the respondents to use a five-point Likert scale. The specific study questions covered a range of management skills including conceptual skills, Human skills and Specialized skills and competencies including conceptual, leadership, Executive, Communication, Knowledge, Behavioral and Managing people competency.

Content validity was given by the HR Committee and sample testing was undertaken on a small group of selected respondents including HR Managers, Product Manager and University professor for feedback. The final questionnaire was established on an independent survey server with a webbased design. A cover letter, participant consent sheet and the questionnaire were e-mailed to all those who were product managers at GIG. After collecting questionnaire, 12 responses were eliminated. Therefore, 30 responses were finally used for analysis. 
Table 2 GIG SENIOR Product Managers Competency Conceptual Model

\begin{tabular}{|c|c|c|c|}
\hline dimention & component & indicators & The Symbol \\
\hline \multirow{4}{*}{ Analytical Skill } & \multirow{4}{*}{ Conceptual } & Strategic Thinking & $\mathrm{C} 11$ \\
\hline & & Creative Thinking & $\mathrm{C} 12$ \\
\hline & & Analytical Thinking & $\mathrm{C} 13$ \\
\hline & & Problem Solving & $\mathrm{C} 14$ \\
\hline \multirow{3}{*}{ Human Skill } & \multirow{3}{*}{ Leadership } & Ability to Influence Others & $\mathrm{C} 21$ \\
\hline & & Training and Development of Individuals & $\mathrm{C} 22$ \\
\hline & & Networking & $\mathrm{C} 23$ \\
\hline \multirow{5}{*}{ Specialized Skill } & \multirow{5}{*}{ Executive } & Planning and Goal Setting & C31 \\
\hline & & Effective Management of Resources & $\mathrm{C} 32$ \\
\hline & & Monitoring and Control & $\mathrm{C} 33$ \\
\hline & & Organization and Coordinating & C34 \\
\hline & & Operation and Business Processes Management & $\mathrm{C} 35$ \\
\hline \multirow{2}{*}{ Human Skill } & \multirow{2}{*}{ Communication } & $\begin{array}{c}\text { Effective Communication } \\
\end{array}$ & $\mathrm{C} 41$ \\
\hline & & Negotiating Power & $\mathrm{C} 42$ \\
\hline \multirow{3}{*}{ Human Skill } & \multirow{3}{*}{ Managing people } & Team-Building and Leading & $\mathrm{C51}$ \\
\hline & & Empowering People & $\mathrm{C52}$ \\
\hline & & Performance Management & $\mathrm{C} 53$ \\
\hline \multirow{2}{*}{ Specialized Skill } & \multirow{2}{*}{ Knowledge } & Specialized Knowledge & C61 \\
\hline & & Organization Awareness & C62 \\
\hline \multirow{9}{*}{ Human Skill } & \multirow{9}{*}{ Behavioural } & Self-Control & C71 \\
\hline & & Responsibility & $\mathrm{C} 72$ \\
\hline & & Flexibility & $\mathrm{C} 73$ \\
\hline & & Commitment and Integrity & $\mathrm{C} 74$ \\
\hline & & Innovation and Creativity & $\mathrm{C} 75$ \\
\hline & & Stress Management & $\mathrm{C} 76$ \\
\hline & & Continuous Learning & $\mathrm{C} 77$ \\
\hline & & Customer- Orientation & $\mathrm{C} 78$ \\
\hline & & Result-Orientation & C79 \\
\hline
\end{tabular}

We used nonparametric tests such as binomial and Friedman tests using SPSS16 to analyze the data. Based on Binomial test, we tested whether or not a criteria is important to managers' competencies and based on Friedman test, we ranked the competencies.

\section{RESULTS}

With regard to the gender of the respondents, $100 \%$ were male managers respectively. This study divided managers into four age groups, namely: 20-30, 31-40, 41-50 and 50 years and above. As shown in Figure 1, the majority of the respondents $73.33 \%$ were in the 20-30 age group followed by $31-40$ age group, covering $3.33 \%$. Similarly, the $41-50$ age group was also significant, covering $20 \%$ of the total respondents of the survey. 50 years and above age groups covered $3.33 \%$ of the total respondents. 


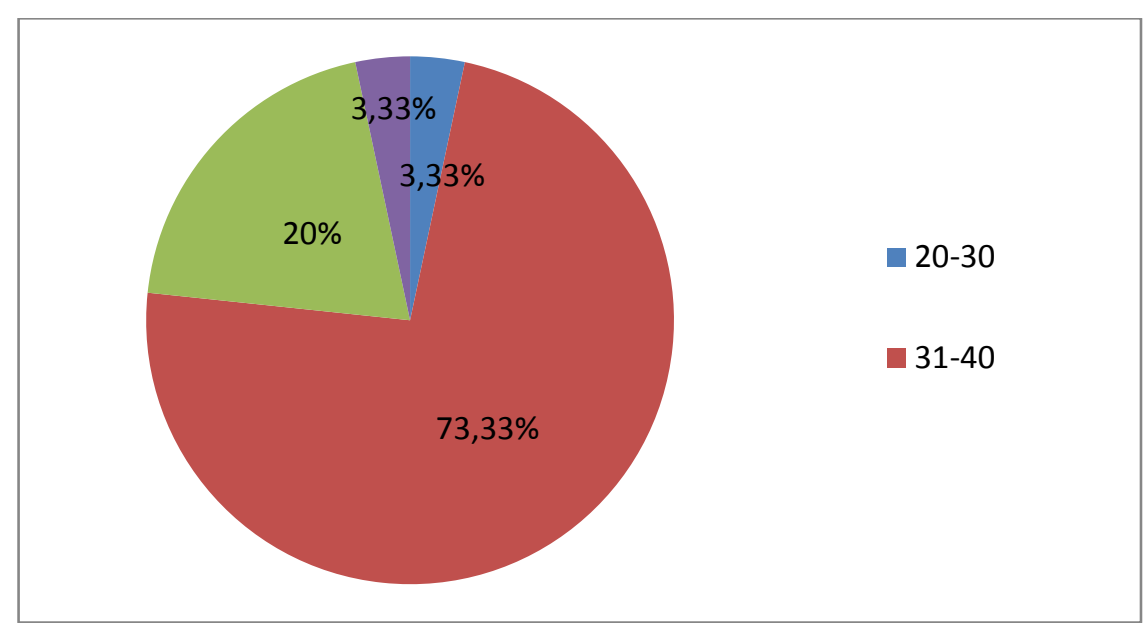

Figure 1 Managers by age groups

The educational qualifications of the respondents are shown in Figure 2. 37\% had a bachelor's degree and $27 \%$ a masters' degree and $37 \%$ had Phd.

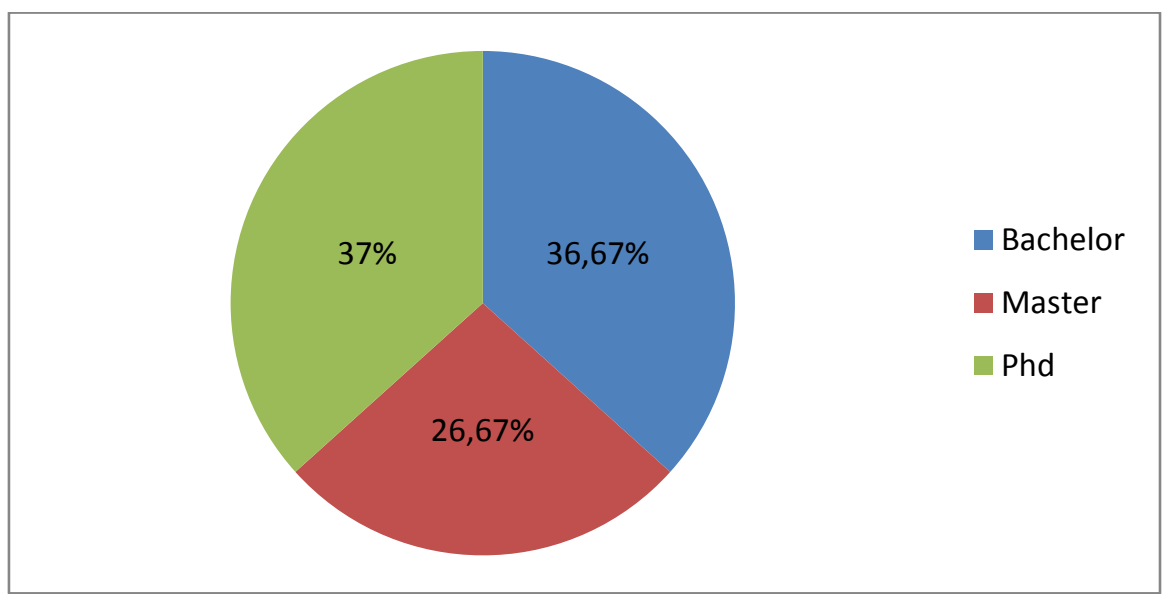

Figure 2 Managers by educational qualification

The Work Experience of the respondents are shown in Figure 3. This study divided managers Work Experience into five groups.

As shown in Figure 3, the majority of the respondents $46.67 \%$ were in the $10-20$ Work Experience group followed by 3-5 group, covering 10\%. Similarly, the 5-10 group was also covering $37 \%$ of the total respondents of the survey, 1-3 group, covering 3.33\% and 20 years and above work experience groups covered $3.33 \%$ of the total respondents. 


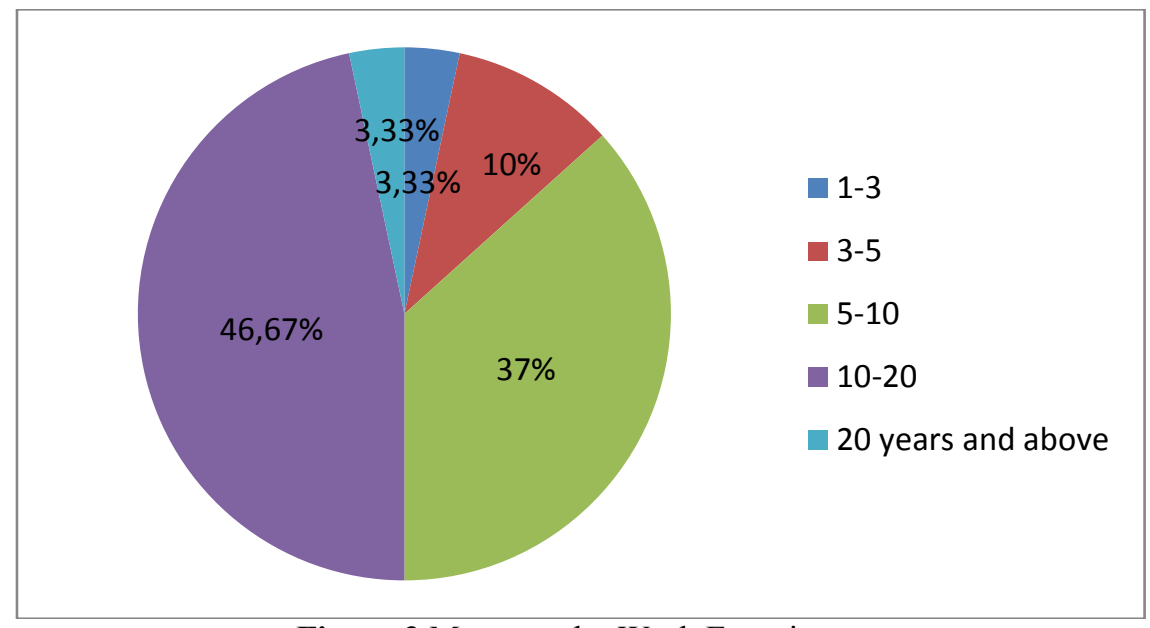

Figure 3 Managers by Work Experience

The survey investigated the importance of the following skills and competencies to enable managers to perform their managerial functions: interpersonal skills, problem-solving skills, teamwork skills, leadership skills, technical skills, communication skills, negotiation skills, and other skills. There were five options available for the respondents to select. The options were 'very important', 'important', 'neither important nor unimportant', 'unimportant', and 'Equal'.

Based on experts' point of view, the importance of none of the components is the same. To rank the competencies, we used Friedman test at a significance level of 5\%. The results are shown in Table 3. Analyzing experts' data from the questionnaire indicated that they view the merits of networking, effective communication, self-control, flexibility and negotiating power as the most important competencies of their senior managers.

\section{DISCUSSION AND CONCLUSIONS}

The senior product managers perform an increasingly important role in the modern work organization. The findings and analysis suggest that both Networking and communication skills are very important for performing managerial jobs. Likewise, Self-Control and Flexibility are also important to product manager. In this study, we identified 28 competencies that define the scope of expertise required by successful senior product managers at GIG. Some of these competencies, such as those labeled "Planning and Goal setting", "Problem-solving" and "Empowerment people" might be relevant for any managerial position. Others, however, such as "Networking", "Operation and Business Management", and "Creative Thinking", incorporate competencies specifically within a production context. Competencies relating to a manager's attitudes or values (Flexibility, Commitment and Integrity, Self-control and Responsibility) appear to be more universal across managerial domains. 
Table 3 Friedman Test

\begin{tabular}{|c|c|c|}
\hline & Mean Rank & Rank \\
\hline C11 & 13.47 & 7 \\
\hline C12 & 13.83 & 10 \\
\hline C13 & 14.85 & 16 \\
\hline C14 & 17.95 & 28 \\
\hline C21 & 13.65 & 8 \\
\hline C22 & 12.97 & 6 \\
\hline C23 & 10.37 & 1 \\
\hline C31 & 16.68 & 26 \\
\hline C32 & 16.72 & 27 \\
\hline C33 & 15.58 & 21 \\
\hline C35 & 15.18 & 18 \\
\hline C41 & 14.08 & 12 \\
\hline C42 & 12.47 & 2 \\
\hline C51 & 16.42 & 5 \\
\hline C52 & 14.5 & 14 \\
\hline C53 & 13.8 & 9 \\
\hline C61 & 16.63 & 25 \\
\hline C62 & 13.93 & 11 \\
\hline C71 & 12.25 & 3 \\
\hline C72 & 15.83 & 23 \\
\hline C73 & 12.32 & 4 \\
\hline C74 & 15.55 & 20 \\
\hline C75 & 14.6 & 15 \\
\hline C76 & 15.15 & 17 \\
\hline C77 & 14.32 & 13 \\
\hline C78 & 15.38 & 19 \\
\hline C79 & 15.73 & 22 \\
\hline
\end{tabular}

The critical issue for senior product managers today is to identify the importance of Human skills beyond merely Analytical and Specialized skills but rather the coaching elements of leadership: to guide and to foster creativity to enhance innovation so GIG will not lag behind but instead lead in excellence. Honesty and trustworthiness are fine attributes, important to instill confidence and are beneficial for motivating employees. However, a far greater emphasis on creativity should also be developed to encourage managers further to shape their futures, rather than be shaped by them. This will enhance GIG innovation environment as well as help the country to position itself better in the global competitive marketplace.

\section{References}

[1] Birdir, K. \& Pearson, T. (2000). Research Chefs' Competencies: A Delphi Approach. International Journal of Contemporary Hospitality Management, 12(3), 205-209.

[2] Bonbright, J. C. \& Means, G. C. (1969). The holding company. New York: Augustus M. Kelley.

[3] Boyatzis, R. E. (1982). The Competent Manager: A Model for Effective Performance. New York: John Willey \& Sons. 
[4] Boyatzis, R. E. (2008). Competencies in the 21st Century. Journal of Management Development, 27(1), 5-12.

[5] Burgoyne, J. (1989). Creating the Managerial Portfolio: Building on Competency Approaches to Management Development. Management Education and Development, 20 (1), 56-61.

[6] Carroll, A. \& McCrackin, J. (1998). The Competent Use of Competency Based Strategies for Selecting and Development. Performance Improvement Quarterly, 11 (3), 45-63.

[7] Chong E. (2011). Managerial Competencies and Career Advancement: A Comparative Study of Managers in Two Countries. Journal of Business Research. In Press.

[8] Delamare Le Deist, F. \& Wintertone, J. (2005). What Is Competence? Human Resource Development International, 8 (1), 27-46.

[9] Echanis, E. S. (2010). Holding companies: A structure for managing diversification. Philippine Management Review.

[10] Gallon, M. R., Stillman, H. M. \& Coates, D. (1995). Putting Core Competency Thinking into Practice. Research Technolog y Management, 38 (3), 20-8.

[11] Hanafizadeh, P., \& Moayer, S. (2008). A methodology to define strategic processes in organizations: An exploration study in managerial holding companies. Business Process Management Journal, 14(2), 219-227.

[12] Hogg, B. (1993). European Managerial Competencies. European Business Review, 93 (2), 21-26.

[13] Horng, J. S., Hsu, H., Liu, Ch. H., Lin, L. \& Tsai, Ch. Y. (2011). Competency Analysis of Top Managers in the Taiwanese Hotel Industry. International Journal of Hospitality Management, 30, 1044-1054.

[14] Lee Katz, Robert. (1974). Skills of an Effective Administrator, Harvard business review classics.

[15] Lucia, A. D. \& Lepsinger, R. (1999). The Art and Science of Competency Models: Pinpointing Critical Success Factors in Organizations. San Francisco: Jossey-Bass.

[16] Mansfield, R. S. (1996). Building Competency Models: Approaches for HR Professionals. Human Resource Management, 35 (1), 7-18.

[17] Mansfield, R. S. (2005). Practical Questions in Building Competency Models.

[18] Martina, K., Hana, U., Jiří, F., Iveta, ̌̌., Abraham, A., Jebapriya, S., ... \& de Matos, A. C. (2012). Identification of managerial competencies in Knowledge-based Organizations. Journal of competitiveness, 4(1), 129-142.

[19] McClelland, D. C. (1973). Testing for Competence Rather Than for Intelligence. American Psychologist, 28, 1-14.

[20] Prahalad, C. K. \& Hamel, G. (1990). The Core Competence of the Corporation. Harvard Business Review, 68 (3), 79-91.

[21] Rothwell, W. J. \& Lindholm, J. E. (1999). Competency Identification Modelling and Assessment in the USA. International Journal of Training and Development, 3 (2), 90-105.

[22] Sanghi, S. (2007). The Handbook of Competency Mapping. New Delhi: Sage Publications India.

[23] Schroder, H. M. (1989). Managerial Competence: The Key to Excellence: A New Strateg y for Management Development in the Information Age. London: Kendall \& Kent Publications. 
[24] Spencer, L. M. \& Spencer S.M. (1993). Competence at Work. New York: John Wisley \& Sons.

[25] Talukder, D., \& Hawkins, B. (2014). Managerial skills and competencies in New Zealand organisations: a cause for concern. International Journal of Economics and Business Research, 8(2), 125-142.

[26] Tate, W. (1995). Developing Managerial Competence. Hampshire: Gower Publishing Limited.

[27] Truneček, J. (2003). Znalostní podnik ve znalostní společnosti. Prague: Professional Publishing.

[28] Ulrich, D. \& Lake, D. (1991). Organizational Capability: Creating Competitive Advantage. Academy of Management Executive, 5 (1), 77-92.

[29] White, R. (1959). Motivation Reconsidered: the Concept of Competence. Psychological Review, 66 (5), 279-333.

[30] Winterton, J. \& Winterton, R. (1999). Developing Managerial Competence. London: Routledge.

[31] Winterton, J. \& Winterton, R. (1999). Developing Managerial Competence. London: Routledge.

[32] Woodruffe, C. (1992). What is Meant By a Competency. In R. Boam \& P. Sparrow (Eds.), Designing and Achieving Competency, (pp.16-29). London: McGraw-Hill. 